\title{
Penggunaan Media Animasi Untuk Meningkatkan Hasil Belajar IPS Tentang Keanekaragaman Budaya Indonesia Siswa Kelas V SDN Cangkringsari Sukodono Sidoarjo
}

\author{
Zuni Eka Tiyas Rifayanti \\ Program Studi PGSD STKIP Bina Insan Mandiri Surabaya \\ zunieka@stkipbim.ac.id
}

\begin{abstract}
This class action research aimed to increasing student learning result through the utilization of animation media on social science. The subject of research is 20 fifth grade students of SDN Cangkringsari Sukodono Sidoarjo. The execution of this research consisted of two cycles and each cycle consisted from several stage namely planning, execution, observation and reflection. The kind of data that collected on this research are teacher's learning activities, student's learning activities and data from student learning result after the application of animation media. Data collected done by multilevel scale systematic observation method to measuring the activity of teacher and student while student learning result using evaluation tool in the form of test. On the data collection activity researcher helped by one observer. Data from this research analyzed descriptive qualitatively. When the process of learning goes well on cycle I and cycle II showing that teacher activity can increased, it indicated by the enhancement of teacher activity on first cycle with percentage as big as $64.16 \%$ and on the action of second cycle with percentage as big as $86.66 \%$ with the enhancement as big as $22.50 \%$. Student's activity on learning activity showing an enhancement from first cycle to second one, on first cycle with percentage as big as $62.69 \%$ and on the action of second cycle with percentage as big as $83.05 \%$ with the enhancement as big as $20.36 \%$. On the student learning result that obtained from first cycle and second cycle, obtained average learning result score on first cycle as big as 61.75 , and on the second cycle as big as 79.75 it showed that after the utilization of animation media on the matter of diversity of Indonesian's cultures can increasing the learning result of fifth grade students of SDN Cangkringsari Sukodono Sidoarjo. Thus, utilization of animation media on the matter of diversity of Indonesian's cultures can increasing teacher's activity, student's activity and student learning result.
\end{abstract}

Keyword: animation media, social science learning, student learning result

\section{PENDAHULUAN}

Perkembangan ilmu pengetahuan dan teknologi telah membawa perubahan hampir pada semua aspek kehidupan manusia, membawa kita ke dalam era persaingan global yang semakin ketat. Agar mampu berperan dalam persaingan global, maka sebagai bangsa kita perlu terus mengembangkan dan meningkatkan kualitas sumber daya manusianya. Dalam dunia Pendidikan di era serba digital ini banyak bermunculan media media berbasis ICT akan tetapi isi software dari materi ajar penunjangnya yang menjadi tantangan kita sebagai praktisi Pendidikan, khususnya bagi guru Sekolah Dasar, untuk dapat menggunakan media berbasis ICT dengan materi ajar berbasis media software.

Upaya yang telah dilakukan untuk meningkatkan hasil belajar pada mata pelajaran IPS belum mencapai hasil yang maksimal, hal ini dibuktikan dengan masih rendahnya perolehan nilai siswa pada ujian akhir sekolah. Berdasarkan data yang diperoleh dari SDN Cangkringsari I Sukodono,dari hasil ulangan harian siswa yang rata-rata tidak tercapainya KKM mata pelajaran IPS yaitu 65 dan hanya memperoleh hasil belajar dibawah KKM Rendahnya hasil belajar tersebut disebabkan berbagai faktor yang terlibat langsung dalam proses pembelajaran, diantaranya faktor guru, siswa, metode mengajar, media pembelajaran, sarana dan prasarana pendidikan yang digunakan maupun materi pelajaran.

Sesuai dengan kemajuan IPTEK, dengan demikian maka proses pembelajaran yang dilakukan harus lebih ditingkatkan. Dalam pembelajaran, khususnya mata pelajaran IPS, 
model pembelajaran langsung yang sering digunakan, yaitu suatumodel pengajaran yang sebenarnya bersifat teacher centered. Pembelajaran langsung dirancang khusus untuk menunjang proses belajar siswa yang berkaitan dengan pengetahuan deklaratif dan pengetahuan prosedural yang terstruktur dengan baik yang dapat diajarkan dengan pola kegiatan bertahap, selangkah demi selangkah.

Karena dalam pembelajaran, peran guru sangat dominan, maka guru dituntut agar dapat menjadi seorang model yang menarik bagi siswa. Sistem pengelolaan pembelajaran yang dilakukan oleh guru harus menjamin terjadinya keterlibatan siswa, terutama melalui memperhatikan, mendengarkan, dan resitasi (tanya jawab) yang terencana. Tidak berarti bahwa pembelajaran bersifat otoriter, dingin dan tanpa humor. Ini berarti bahwa lingkungan berorientasi pada tugas dan memberi harapan tinggi agar siswa mencapai hasil belajar yang baik.

Selain hal tersebut dalam suatu kegiatan proses belajar mengajar guru harus mampu mengkolaborasikan dengan apik antara model pembelajaran , materi ajar, dan tentunya menggunakan media media pembelajaran penunjang yang efektif demi ketercapaian tujuan pembelajaran.

Menurut Ariani Niken (2010), animasi menjadi pilihan untuk menujang proses belajar yang menyenangkan dan menarik bagi siswa dan juga memperkuat motivasi, dan juga untuk menanamkan pemahaman pada siswa tentang materi yang diajarkan. Animasi yang pada dasarnya adalah rangkaian gambar yang membentuk sebuah gerakan memiliki keunggulan dibanding media lain seperti gambar statis atau teks. Animasi untuk menarik perhatian siswa dan memperkuat motivasi, biasanya berupa tulisan atau gambar yang bergerak-gerak, animasi yang lucu, aneh yang sekiranya akan menarik perhatian siswa. Keunggulan animasi dalam hal ini gambar yang bergerak adalah kemampuannya untuk menjelaskan suatu kejadian secara sistematis dalam tiap waktu perubahan. Hal ini sangat membantu dalam menjelaskan prosedur dan urutan kejadian. Animasi gambar dibuat dengan bantuan program Power Point, Sedangkan animasi yang berupa kata atau tulisan yang bergerak menggunakan software $\mathrm{CD}$ pembelajaran interaktif edu game.

Berdasarkan uraian-uraian tersebut di atas, peneliti mengambil judul tentang "Penggunaan Media Animasi untuk Meningkatkan Hasil
Belajar IPS tentangKeanekaragaman Budaya Indonesia Pada SiswaKelas V SDN Cangkringsari Sukodono Sidoarjo.

Berdasarkan latar belakang di atas, maka rumusan masalah yang dikemukakan dalam penelitian ini adalah :

1. Bagaimana aktivitas guru dalam penggunaanmedia animasi untuk sumber belajar dapat meningkatkan hasil belajar siswa pada materi keanekaragaman budaya Indonesia klas V SDN Cangkringsari Sukodono Sidoarjo?

2. Bagaimana aktivitas siswa selama penggunaan media animasi pada materikeanekaragaman budaya Indonesia di klas V SDN Cangkringsari Sukodono Sidoarjo?

3. Bagaimana hasil belajar siswa setelah penggunaan media animasi pada materi keanekaragaman budaya Indonesia di klas V SDN Cangkringsari Sukodono Sidoarjo ?

4. Kendala apa saja yang muncul selama penggunaan media animasi sebagai sumber belajar dapat meningkatkan hasil belajar siswa tentang keanekaragaman budaya Indonesia di klas V SDN Cangkringsari Sukodono Sidoarjo?

\section{METODE PENELITIAN}

Penelitian ini merupakan penelitian tindakan kelas (Classroom Action Research). Penelitian ini dilaksanakan di SDN Cangkringsari Sukodono Sidoarjo, yang berlokasi di jalan Cangkringsari kecamatan Sukodono kabupaten Sidoarjo.

Penelitian ini dilaksanakan melalui beberapa siklus berulang dan setiap siklus terdiri atas empat langkah yaitu perencanaan tindakan, pelaksanaan tindakan, observasi dan refleksi. Model pelaksanaan PTK ini menggunakan model PTK kolaboratif dengan acuan yang digunakan adalah model siklus PTKGambaran tentang pelaksanaan penelitian yang terdiri beberapa siklus berulang, dapat dilihat pada diagram berikut: 


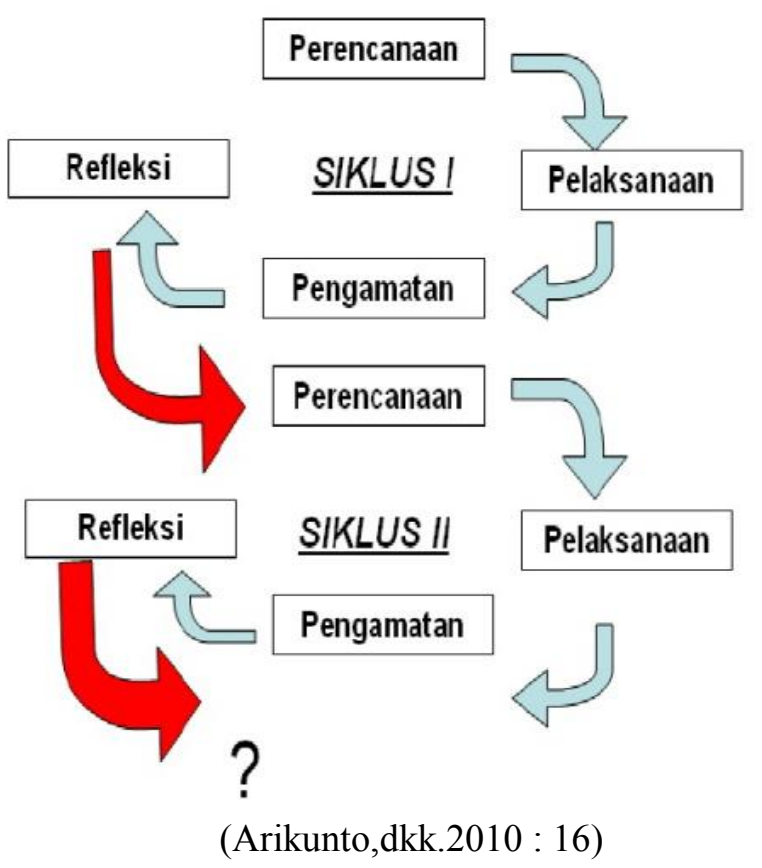

Data yang diperlukan dalam penelitian ini adalah:

1. Hasil pengamatan tentang aktivitas guru dan siswapembelajaran.

2. Hasil pekerjaan siswa berupa nilai ulangan IPS tentang keanekaragaman budaya di Indonesia untuk mengetahui hasil belajar siswa.

3. Instrumen yang digunaan dalam penelitian ini adalah sebagai berikut :

4. Lembar soal Tes hasil belajar yang diberikan disetiap akhir siklus, berupa tes berbentuk pilihan ganda yang dikembangkan oleh peneliti berdasarkan tujuan pembelajaran

5. Lembar observasi atau lembar pengamatan digunakan untuk mengetahui kemampuan guru di dalam melaksanakan RPP yang

$$
\text { Keberhasil an Aktifitas Peneliti }=\frac{\sum \text { indikator kegiatan yang muncul }}{\sum \text { seluruh indikator }} \times 100 \%
$$

Kemudian dikelompokkan berdasarkan pengkategorian kriteria kelulusan dengan batas-batas nilai kelulusan sebagai berikut :

Rentang Skor
$80 \%$ s.d. $100 \%$
$70 \%$ s.d. $79 \%$
$60 \%$ s.d $69 \%$
$45 \%$ s.d $59 \%$
$\leq 44 \%$

(Rasyid, Harun 2008 : 21) telah dibuat yaitu berupa penerapan Pembelajaran Langsung dengan media animasi, serta untuk mengetahui aktifitas guru dan aktifitas siswa selama proses pembelajaran berlangsung.

6. Wawancara berupa pertanyaan tertulis yang digunakan untuk memperoleh data dari responden terhadap penggunaan media animasi.

Metode pengumpulan data yang digunakan oleh peneliti untuk memperoleh data-data yang dibutuhkan dalam penelitian adalah metode observasi dan tes.Data kualitatif dari hasil pengamatan (observasi) dengan menggunakan lembar pengamatan yang dilakukan pada saat pembelajaran berlangsung dianalisis secara kualitatif.
Sedangkan data kuantitatif yang berupa hasil belajar siswa, dari jumlah skor yang diperoleh dari kegiatan pengumpulan data selanjutnya dianalisis untuk menentukan nilai hasil belajar yang diperoleh dengan mengu-bahnya yang menggunakan rumus sebagai berikut:

$\mathrm{P}=\frac{f}{N} X 100 \%$

Keterangan :

$\mathrm{P}=$ Prosentase

$\mathrm{F}=$ Jumlah skor yang diperoleh

$\mathrm{N}=$ Jumlah skor maksimal semua komponen .

(Winarsunu, 2009 : 20) 
Sesuai dengan tujuan penelitian yaitu untuk meningkatkan hasil belajar IPS, diadakan penelitian tindakan yang berorientasi penggunaan media animasi dalam model pembelajaran langsung. Untuk mengetahui keberhasilan tersebut digunakan nilai ketercapaian yaitu $80 \%$ dari jumlah siswa mencapai batas nilai ketuntasan belajar yaitu 65. Digunakan nilai ketuntasan belajar 65 karena disesuaikan dengan standar KKM yang digunakan di sekolah SDN Cangkringsari Sukodono Sidoarjo. Dan untuk mengetahui keberhasilan aktivitas guru dan siswa digunakan nilai ketercapaian $80 \%$.

\section{HASIL \& PEMBAHASAN}

Hasil penelitian yang diperoleh menunjukkan adanya peningkatan hasil belajar siswa kelas $\mathrm{V}$ yang diajar dengan menggunakan media animasi dalam model pembelajaran langsung. Pernyataan ini didukung oleh hasil analisis data secara deskriptif yang dapat dilihat pada tabel 14, hasil belajar IPS siswa kelas V SDN Cangkringsari untuk siklus I berada pada kategori Cukup, dengan melihat bahwa jumlah siswa tertinggi setelah pengelompokan hasil belajar berada pada interval $60-69$ (cukup) sebanyak 10 orang atau $50 \%$. Sedangkan pada siklus II jumlah siswa terbanyak berada pada kategori baik sekali dengan jumlah siswa 11 orang atau $55 \%$.

Sesuai dengan tujuan penelitian yaitu untuk meningkatkan hasil belajar IPS, diadakan penelitian tindakan yang berorientasi penggunaan media animasi dalam model pembelajaran langsung. Untuk mengetahui keberhasilan tersebut digunakan nilai ketercapaian yaitu $75 \%$ dari jumlah siswa mencapai batas nilai ketuntasan belajar yaitu 65. Digunakan nilai ketuntasan belajar 65 karena disesuaikan dengan standar umum yang digunakan di sekolah.

Hasil belajar siklus I menunjukkan nilai tertinggi 85 , nilai terendah 35 , rata-rata 61,75 . Sedangkan untuk siklus II, nilai tertinggi 100 , nilai terendah 50 , rata-rata 79,75 . Apabila nilai rata-rata dibandingkan dengan tabel pedoman pengkategorian hasil belajar, maka baik untuk siklus I maupun siklus II berada pada kategori baik. Bisa dikatakan tidak meningkat, tetapi bila dilihat lagi terjadi peningkatan nilai ratarata sebesar 18,00 dari siklus I ke siklus II, jadi dapat dikatakan meningkat. Rasyid, Harun (2008) mengatakan bahwa, keberhasilan pengajaran dapat dilihat dari (1) peningkatan nilai rata-rata, (2) perubahan bentuk distribusi dari miring positif menjadi miring negati, dan (3) koefisien variansi semakin kecil.

Pengkategorian berdasarkan kriteria ketuntasan belajar, maka dari 20 siswa yang mengikuti tes siklus I, sebanyak 15 siswa atau $75 \%$ yang termasuk kategori tidak tuntas dengan rentang skor 0 hingga 69. Siswa yang termasuk dalam kategori tuntas dengan rentang skor 70 hingga 100 sebanyak 5 siswa atau 25 $\%$. Sedangkan pada siklus II dari 20 siswa yang mengikuti tes evaluasi, sebanyak 1 siswa yang termasuk kategori tidak tuntas atau sebesar 5\%. Siswa yang termasuk dalam kategori tuntas sebanyak 19 siswa atau sebesar 95\%. Meningkatnya hasil belajar siswa disebabkan karena penggunaan media animasi dalam pembelajaran langsung, sehingga siswa lebih bersemangat dan bergairah dalam menerima pelajaran. Dimana animasi mampu mengarahkan kepada sesuatu proses yang yang menjadikan suatu objek agar kelihatan hidup atau memberi gambaran bergerak kepada sesuatu yang pada dasarnya statik, sehingga mampu mengantar imajinasi siswa kepada suatu proses yang sesungguhnya terjadi.

Aktivitas dan semangat siswa dalam belajar mengalami peningkatan dari tiap siklus, serta perilaku negatif yang sering diperlihatkan siswa dalam proses pembelajaran juga mengalami penurunan dari tiap siklus. Hal ini dapat dilihat dengan membandingkan rata-rata hasil observasi antara siklus I dan siklus II.Meningkat atau menurunnya aktivitas siswa itu tidak lain dari hasil refleksi yang dilakukan pada akhir siklus I dimana dari beberapa catatan yang dijadikan sebagai bahan refleksi dari siklus I itu kemudian diambil sebagai bentuk penanggulangan masalah yang terjadi yang kemudian diterapkan pada siklus II. Adapun hasil refleksi dari siklus I ini adalah interaksi diantara siswa dalam kelompok kurang dalam mengerjakan LKS. Hal ini disebabkan, karena siswa yang tidak bisa menerima siswa yang menjadi anggota kelompoknya karena biasanya siswa membentuk kelompok belajar cenderung memilih temannya yang lebih dekat. Ada beberapa siswa di dalam satu kelompok yang tidak aktif bekerjasama menyelesaikan LKS, karena ia mengharapkan teman kelompoknya yang lain untuk mengerjakan. Gambar tentang materi dalam LKS sedikit dan kurang efektifnya penggunaan LKS sebagai sarana belajar. Ini terlihat dari jawaban siswa pada tes siklus I, dimana beberapa item soal yang diujikan diangkat dari soal pada LKS dan kebanyakan siswa menjawab salah. Siswa 
masih tidak disiplin dalam belajar, hal ini dapat dilihat dari sejumlah siswa pada saat pelajaran berlangsung masih ada yang belajar/mengerjakan pelajaran lain, keluar masuk kelas dan mengganggu temannya dan adanya siswa yang berjalan-jalan di dalam kelas.Dari tes hasil belajar yang diperoleh pada siklus I persentase siswa yang dinyatakan tuntas sebesar 25\%, masih rendah dari indikator keberhasilan penelitian yaitu $80 \%$.Kendala - kendala yang dialami pada waktu penggunaan media animasi diantaranya yaitu pada saat listrik mati maka penggunaan media animasi tidak bisa digunakan. Karena penggunaan media animasi ditunjang dengan perangkat komputer, laptob, LCD, speaker yang semua alatnya perlu daya listrik. Selain itu pencahayaan kondisi ruang kelas yang tidak maksimal mengakibatkan animasi yang ditayangkan kurang terlihat jelas.

Penelitian yang dilakukan hanya sampai siklus II dan tidak dilanjutkan lagi karena sesuai dengan standar ketuntasan peneliti bahwa penelitian dikatakan berhasil apabila $80 \%$ dari siswa dalam kelas sudah mencapai nilai standar yaitu 65. Disamping itu ada juga namanya ketuntasan kelas, suatu pembelajaran dikatakan berhasil apabila $80 \%$ dari jumlah siswa dinyatakan tuntas. Mengenai kapan penelitian dihentikan untuk siklus berikutnya, apabila perubahan yang bertujuan meningkatkan kualitas pembelajaran telah tercapai, atau apapun diteliti telah menunjukkan keberhasilan siklus, yaitu apabila apa yang direncanakan sudah berjalan sebagaimana diharapkan, dan data yang ditampilkan dalam kelas sudah jenuh, dalam arti tidak ada data baru yang ditampilkan dan dapat diamati, serta kondisi kelas dalam pembelajaran sudah mampu dikuasai, maka penelitian dihentikan. Jadi banyaknya siklus dalam penelitian tindakan kelas tergantung pada kondisi yang stabil dan data yang sudah jenuh.

Berdasarkan hasil penelitian dan uaraian pembahasan di atas diperoleh informasi bahwa penggunaan media animasi dalam pembelajaran langsung dapat meningkatkan hasil belajar IPS siswa kelas V SDN Cangkringsari.

\section{KESIMPULAN \& SARAN}

Berdasarkan hasil penelitian, analisis data, dan pembahasan, maka dapat disimpulkan bahwa penggunaan media animasi dalam pembelajaran langsung meningkatkan hasil belajar IPS siswa kelas V SDN Cangkringsari.
Dari hasil penelitian yang berkaitan dengan tujuan penelitian dapat disimpulkan sebagai berikut :

1. Aktivitas guru selama penggunaanmedia animasi menunjukkan terjadi peningkatan aktivitas guru dari tindakan siklus Idan pada tindakan siklus II , hal ini menunjukkan bahwa penggunaan media animasi dalam mata pelajaran IPSmateri Keanekaragaman Budaya di Indonesia untuk meningkatkan hasil belajar pada siswa kelas $\mathrm{V}$ SDN Cangkringsari kecamatan Sukodono dapat meningkatkan aktivitas guru dalam pembelajaran.

2. Aktivitas siswa selama penggunaan media animasi dalam materi Keanekaragaman Budaya di Indonesia dari tindakan siklus I dan tindakan siklus II menunjukkan terjadi peningkatan aktivitas siswa dan sudah memenuhi kriteria ketuntasan minimal, ini menunjukkan bahwa penggunaan media animasi dalam mata pelajaran IPSmateri Keanekaragaman Budaya di Indonesia untuk meningkatkan hasil belajar pada siswa kelas V SDN Cangkringsari kecamatan Sukodono dapat meningkatkan aktivitas siswa.

3. Hasil belajar siswa selama proses pembelajaran, tindakan siklus I dan siklus II terjadi peningkatan dan sudah memenuhi kriteria ketuntasan minimal yang sudah ditentukan, ini menunjukkan bahwa setelah penggunaan media animasi dalam mata pelajaran IPSmateri Keanekaragaman Budaya di Indonesiadi kelas V SDN Cangkringsari 1 kecamatan Sukodono dapat meningkatkan hasil belajar siswa.

4. Kendala -kendala yang ditemui pada saat penggunaan media Animasi dalam materi Keanekaragaman Budaya di Indonesia untuk meningkatkan hasil belajarIPS pada siswa kelas V SDN Cangkringsari kecamatan Sukodono adalah pada saat menulis pokok penting dari tampilan slide karena baru pertama kali dilakukan siswa, sehingga waktu yang dibutuhkan lama, dan Pada waktu pnerapan media animasi terjadi hujan lebat yang mengakibatkan listrik mati sehingga waktu harus tertunda sejenak sampai listriknya menyala.

Sehubungan dengan kesimpulan hasil penelitian di atas, maka saran yang dapat dikemukakan oleh peneliti adalah:

1. Mata pelajaran IPS sebaiknya disampaikan dengan dukungan penggunaan media animasi pada pembelajaran langsung. Hal 
ini akan meningkatkan motivasi dan keingintahuan siswa sehingga hasil belajar yang diperoleh dapat maksimal.

2. Media animasi dan lembar kerja siswa yang telah dibuat perlu terus dikembangkan dan direvisi agar benar-benar dapat membantu siswa dalam memahami materi pelajaran IPS.

3. Agar guru melakukan inovasi pembelajaran terutama dalam pembuatan media untuk membantu proses pembelajaran.

4. Guru harus selalu menggunakan media dalam proses pembelajaran sehingga dapat meningkatkan aktivitas siswa.

5. Diharapkan pada peneliti selanjutnya agar dapat mengembangkan dan memperkuat hasil penelitian ini dengan mengadakan penelitian lebih lanjut.

\section{DAFTAR PUSTAKA}

Abdurrahman, M. 1999. Pendidikan Bagi Anak Berkesulitan Belajar. Jakarta: Rineka Cipta.

Ariani, Niken. 2010. Pembelajaran Multi Media di Sekolah. Jakarta : PT Prestasi Pustaka Raya

Arikunto, Suharsimi. 2006. Prosedur Penelitian. Jakarta. Rineka Cipta

-----2010.Penelitian

Tindakan Kelas.Jakarta:Bumi Aksara

Arsyad, Azhar.2009. Media Pembelajaran. Jakarta. PT Raja Grafindo Persada

Bandono. A. 2003. Model Pembelajaran Langsung.http://beta.tnial.mil.id/ cakrad.php3?id=150. Diakses tanggal 25 Agustus 2011.

Beetlestone, Florence. 2011. Creative Learning. Bandung: Nusa Media

Bagget. 1991. Media Visualisasi Pembelajaran. Jakarta : Rajawali Pers

Djamarah,BS dan A.Zain. 2010. Strategi Belajar Mengajar. Jakarta:Rineka Cipta.

Filsaime, Dennis K. 2008. Menguak Rahasia Berpikir Kritis dan Kreatif.Jakarta : Prestasi Pustakarya

Julianto, dkk. 2011. Teori dan Implementasi Model-model Pembelajaran Inovatif. Surabaya : Unesa University Press

Mulyasa, E. 2008. KTSP. Bandung: Remaja Rosada Karya

Nani Rosdjijati, dkk. 2010. Pembelajaran IPS \& Lingkungan. Jakarta.PT Raja Grafindo Persada.

Nasution. W. N.. 2006. Efektivitas Strategi Pembelajaran Kooperatif dan Langsung terhadap Hasil Belajar Sains Ditinjau dari Cara Berpikir.http://ligatama.org.

Diakses pada tanggal 25 November 201

Rassyid, Harun. 2008. Penilaian Hasil Belajar. Bandung: CV Wacana Prima.

Ridwan, 2009. Metode \& Teknik Menyusun Proposal Penelitian.Bandung : ALFABETA

Rusdianto. 2006. Pengaruh Penggunaan Media Animasi pada Model Pembelajaran Langsung terhadap Hasil Belajar Biologi Siswa Kelas XI MA Negeri Malang pada Konsep Sistem Pencernaan. Skripsi. Malang: Fakultas Matematika dan Ilmu Pengetahuan Alam Universitas Negeri Makassar.

Sadiman, Arif S. dkk. 2009. Media Pendidikan. Jakarta : Rajawali Pers

Slameto. 2003. Belajar danFaktor yang Mempengaruhinya. Jakarta: PT Asdi Mahasatya.

Sudjana, Nana. 2005. Dasar-dasar Proses BelajarMengajar . Bandung: Sinar Baru Algensindo

Susilahningsih, Endang. 2008. IPS SD/MI Kelas 5 BSE .Jakarta : Depdiknas

Susilana, dkk. 2008. Media Pembelajaran. Bandung: CV. Wacana Prima

Syah, Muhibin. 2008. Psikologi Belajar. Jakarta.PT Raja Grafindo Persada.

Trianto. 2007. Model-Model Pembelajaran Inovatif BerorientasiKon-struktivistik. Jakarta : Prestasi Pustaka

Utami, D. 2007. Animasi dalam Pembelajaran. www.uny.ac.id/akademik/ default.php. Diakses pada tanggal 25 Agustus 2011.

Waspodo dan Suhanadji. 2003. Pendidikan IPS. Surabaya. Insan Cendekia 